\title{
JEDNOSTKA PAREMICZNA W EUROPEJSKICH \\ I AMERYKAŃSKICH NURTACH LINGWISTYCZNYCH
}

\author{
PAREMIOLOGICAL UNITS IN EUROPEAN \\ AND AMERICAN TRENDS IN LINGUISTICS
}

\author{
TOMASZ SZUTKOWSKI
}

\begin{abstract}
This article contains a review of modern paremiological trends, especially in French, Czech, Finnish, Estonian and American science centers. The author presents a synthesis of recent research studies with regard to different aspects of and problems associated with this issue.
\end{abstract}

Tomasz Szutkowski, Uniwersytet Szczeciński, Szczecin - Polska.

W 1960 roku na łamach „Cahiers de lexicologie” francuski językoznawca i semiolog Algirdas Julien Greimas, analizując kwestię cech definicyjnych przysłowia, stwierdził, iż „rzadko która katedra gotycka skupia w sobie wszystkie cechy charakterystyczne gotyku"1. Rzecz naturalnie dotyczyła nie historii sztuki, lecz wciąż aktualnego problemu zdefiniowania jednostki paremicznej i jej ścisłego centrum, czyli przysłowia właściwego². Dyskusja nad precyzyjnym określeniem jego cech dyferencjalnych ${ }^{3}$ trwa $w$ zasadzie nieprzerwanie od czasów Arystotelesa i jak dotąd nie należy spodziewać się jej rychłego zakończenia. Rzeczywiście trudno doszukiwać się przykładów prototypowej jednostki paremicznej, która posiadałaby komplet prowerbialnych parametrów. Sytuację tę da się jednak pogodzić ze zjawiskiem

1 A.J. G r e i m a s, Les Proverbes et le dictons, "Cahiers de lexicologie” 1960, vol. 2; przedruk, [w:] „Pamiętnik Literacki” 1978, z. 4, s. 309-314.

2 Por. J. K r z y ż a n o w s k i, Dzieje przystowia polskiego w toku pięciu wieków, [w:] Nowa ksiega przysłów i wyrażeń przystowiowych polskich, pod red. J. Krzyżanowskiego, t. I, Warszawa 1969, s. VIII; T. S z u t k o w s k i, Przystowie wtaściwe jako centralna jednostka w systemie paremiologicznym, [w:] Stowo. Tekst. Czas X. Jednostka frazeologiczna w tradycyjnych i nowych paradygmatach naukowych, pod red. M. Aleksiejenki i H. Waltera, Szczecin 2010, s. 347-355.

3 J. Krzyżanowski wymienia następujące cechy dyferencjalne przysłowia właściwego: 1) jest zdaniem (prostym lub złożonym), 2) ma dwa znaczenia - dosłowne i przenośne, 3) wyróżnia się obrazowością, 4) ma charakter dydaktyczny, 5) jest względnie stabilne i niezmienne pod względem formy, 6) jest powszechnie znane; J. K r z y ż a n o w s k i, op. cit., s. VII-VIII. 
genologicznego zróżnicowania paremii i z ich niejako koncentrycznym usytuowaniem na swoistych paremiologicznych "powłokach elektronowych" wokół wspomnianego przysłowia właściwego ${ }^{4}$. Paremiologię polską i rosyjską różni spośród wielu jeden zasadniczy fakt. Pierwsza - mniej więcej od lat 50. XX w. - była zdominowana przez paradygmat literaturoznawstwa, zgodnie z tradycją szkoły J. Krzyżanowskiego ${ }^{5}$. Druga - głównie dzięki badaniom G.L. Permiakowa ${ }^{6}$ - rozwijała się w duchu strukturalizmu, aby później przejść w fazę metodologii szeroko pojętej lingwistyki kulturowej i kognitywizmu.

Ten istotny fakt zadecydował o wpływach, jakie wywarły na słowianską (zwłaszcza rosyjską) paremiologię założenia europejskich i amerykańskich nurtów lingwistycznych, w polskiej literaturze przedmiotu szerzej nieznane i rzadko cytowane. Chociażby tylko z tego względu warto zwrócić uwagę na rozważania kilku najsilniejszych i najbardziej znaczących ośrodków badawczych skupiających wybitnych językoznawców - paremiologów i paremiografów. Wymiana nierzadko sprzecznych teorii naukowych pozwoli dokładniej przyjrzeć się istocie przysłów oraz precyzyjniej opisać ich cechy strukturalno-semantyczno-funkcjonalne. Dalsze wnikliwe badania jednostek paremicznych, zwłaszcza $\mathrm{w}$ aspekcie formalnym, są ważne z punktu widzenia współczesnej translatoryki, szeroko rozumianej frazeologii i leksykografii. Nie mniej istotne są analizy przysłów w aspekcie funkcjonalnym we współczesnej literaturze, prasie, Internecie oraz w żywym języku mówionym ${ }^{7}$. Warto też zwrócić uwagę na bardzo pozytywne zjawisko $\mathrm{w}$ paremiologii, jakim jest stopniowe zatrzymanie tendencji do zanikania przysłów, o której już ponad dwadzieścia lat temu pisała D. Buttler8. Przejawem tego zjawiska są coraz liczniejsze transformacje paremiczne, nazywane też niezbyt trafnie antyprzysłowiami ${ }^{9}$. Obserwowany od kilkunastu lat swoisty renesans badań paremiologicznych skłania również do syntezy poglądów i teorii wypracowanych w różnych miejscach Europy i w Stanach Zjednoczonych.

4 Por. М.А. А л е к с е е н к о, Еще раз о нерешенных проблемах фразеологии, „Slavica Stetinensia" 1998, nr 8, s. 83-103.

5 Por. W. K o w a l s k i, Z pogranicza nauki o literaturze i językoznawstwa. Paremiologia Juliana Krzyżanowskiego, „Przegląd Humanistyczny” 1982, vol. 11, s. 67-71.

6 Por. Г.Л. П е р м я к о в, Основы структурной паремиологии, Москва 1988.

7 Por. В. М о к и е н к о, Славянская паремиология сегодня (аспекты исследования), [w:] Stowo. Tekst. Czas XI. Frazeologia słowiańska w aspekcie onomazjologicznym, lingwokulturologicznym i frazeograficznym, pod red. M. Hordy, W. Mokijenki, T. Szutkowskiego i H. Waltera, Szczecin 2012, s. 78-100.

8 D. B u t t l e r, Dlaczego zanikaja przysłowia w dwudziestowiecznej polszczyźnie?, „Poradnik Językowy" 1989, z. 5, s. 332-337.

9 Por. Х. В а л ь т е р, В.М. М о к и е н к о, Антипословицы русского народа, Санкт-Петербург 2005. 


\section{Francuskie badania paremiologiczne}

Początek ożywionych zainteresowań paremiologią wśród francuskich badaczy obserwuje się $\mathrm{w}$ latach 60 . XX w., co właściwie pokrywa się z analogiczną tendencją w Polsce i krajach byłego Związku Radzieckiego. Jest to okres silnego oddziaływania na badania paremiologiczne metodologii semiotycznej i strukturalizmu, co wyraźnie widać w pracach cytowanego na wstępie niniejszego artykułu A.J. Greimasa ${ }^{10}$. Francuski językoznawca i semiolog zwraca uwagę na następujące prowerbialne parametry przysłów: 1) są elementami ciągu syntagmatycznego, 2) są konotowane, 3) często mają charakter archaiczny (mowa o ich konstrukcji gramatycznej), 4) ich struktura jest zrytmizowana, binarna i zamknięta. A.J. Greimas kładzie szczególny nacisk na formę archaizującą przysłów, która - według niego - czyni jednostki paremiczne ponadczasowymi, ahistorycznymi, a więc wyłączonymi z czasowości, przez co $\mathrm{w}$ ocenie użytkowników zyskują one rangę skarbnicy prawd moralnych i wiedzy o świecie. Dyskusyjna wydaje się gramatyczna archaiczność przysłów jako ich cecha obligatoryjna. Bez trudu bowiem można przytoczyć szereg przykładów paremii nie wzbudzających wśród współczesnych użytkowników żadnych wątpliwości co do swojej poprawności gramatycznej - oczywiście z perspektywy synchronnicznej (np. Czego Jaś się nie nauczyt, tego Jan nie będzie umiat; Diabet się w ornat ubrat i ogonem na msze dzwoni; Praca z ochota przerabia słomę w złoto; Kon ma cztery nogi, a też się potknie). Kolejna wątpliwość pojawia się przy okazji konstatacji dotyczącej zależności pomiędzy archaicznością a ponadczasowością przysłów. Jeśli zatem nie wszystkie przysłowia - należałoby nawet powiedzieć: ich zdecydowana mniejszość11 - zawierają jakiekolwiek gramatyczne relikty przeszłości językowej, a wszystkie przekazują treści natury uniwersalnej, to wniosek trzeba wysnuć całkiem odmienny. Ponadczasowa aktualność jednostek paremicznych tkwi w ich uniwersalności i globalnym znaczeniu utworzonym na bazie powtarzalnej i typowej sytuacji12. Relikty gramatyczno-leksykalne są niewątpliwie rezultatem formalnej stabilności wszelkiego typu jednostek paremicznych ${ }^{13}$, ale ich konsekwencją jest głównie

10 A.J. G r e i m a s, Idiotismes, proverbes, dictons, "Cahiers de lexicologie" 1960, vol. 2; tegoż, Les proverbes et les dictons, [w:] Du sens. Essais sémiotiques, Paris 1970.

11 Według wyliczeń M. Lipińskiej 28\% francuskich i 6\% polskich przysłów zawiera archaizmy gramatyczne i leksykalne. Por. M. L i p i ń s k a, Les proverbes prototypiques polonais et français, Łask 2003, s. 136.

12 T. S z u t k o w s k i, Jednostki paremiologiczne z komponentem onomastycznym we wspótczesnym języku rosyjskim i polskim, Szczecin 2010, s. 77. Por. także D. B r a l e w s k i, Czy przystowie jest jednostka jezyka?, [w:] Problemy frazeologii europejskiej, t. VII, Lublin 2005, s. 19.

${ }^{13} \mathrm{O}$ petryfikacji struktury jednostek paremicznych pisał m.in. P. A n a u d, La conaissance des proverbes français par les locuteurs natifs et leur sélection didactique, "Cahiers de lexicologie" 1992, vol. LX, s. 198. 
subiektywne poczucie owej czasowej archaiczności przysłów wśród współczesnych użytkowników danego języka. Cechę tę za definicyjną uznaje również J.M. Klinkenberg14.

Francuscy badacze zwracają też uwagę na generyczność lub - inaczej - gnomiczność przysłów ${ }^{15}$. Zdania generyczne, do jakich zaliczają się przysłowia, w przeciwieństwie do zdań zwykłych (pospolitych, niegenerycznych) „przedstawiają pewien stan rzeczy ogólny, stały lub pospolity” 16 . Omawiając cechy definicyjne priameli, M. Lipińska odwołuje się także do badań G. Kleibera, który zauważa, że aby określone zdanie mogło być uznane za generyczne, musi zwierać syntagmę odnoszącą się do pewnej klasy zjawisk, nie natomiast do konkretnych okurencji17. M. Lipińska za G. Kleiberem stwierdza, iż przysłowia mają charakter gnomiczny (nieakcydentalny) oraz wyrażają sytuację lub stan potencjalny, a nie realny, oparty na ściśle określonym przypadku lub zdarzeniu ${ }^{18}$. Wniosek ten należy uznać za w pełni uzasadniony i zgodny z konstatacjami słowiańskich paremiologów. Różnica dotyczy jedynie przyjętego aparatu terminologicznego. Globalność i generyczność semantyczna w powiązaniu ze składniową autonomicznością ${ }^{19}$ czyni przysłowie znakiem językowym sensu stricte.

Dyskusyjna wydaje się także inna cecha przysłów, jaką jest dyskursywna autonomiczność, podkreślana m.in. w pracy P. Arnauda ${ }^{20}$. Owa wątpliwość rodzi się w odniesieniu do względnej kontekstualnej niezależności jednostek paremicznych i ich tekstowej samowystarczalności. Badania ankietowe przeprowadzone w Polsce przez G. Szpilę wskazują jednoznacznie, że „użycie kontekstowe [przysłów] jest niestałe diachronicznie - typowe sytuacje paremiczne zmieniają się jednakże dzięki globalnemu znaczeniu, które dopasowujemy do coraz to nowych sytuacji" ${ }^{21}$. Rzecz dotyczy nie tylko przysłów zapomnianych, które z oczywistych względów mogą być

14 J.M. K 1 i n k e n b e r g, Style et Archad'sme dans la légende d'Ulenspiegel de Charles De Coster, t. II, Bruxelles 1973, s. 112.

15 Por. M. L i p i ń s k a, Cechy definicyjne francuskich priameli, [w:] Problemy frazeologii europejskiej, t. VIII, Lublin 2007, s. 95.

${ }^{16}$ S.Y. K u r o d a, Le jugement catégorique et le jugement thétique. Exemples tirés de la syntaxe japonaise, „Langages” 1973, vol. 29, s. 88; cyt. za: M. L i p i ń s k a, Cechy definicyjne francuskich priameli..., op. cit.

17 Ibidem.

${ }_{18}$ G. K 1 e i b e r, Sur la definition du proverb, [w:] A. C o 1 i n, Nominales, Paris 1994, s. 207-224; cyt. za: M. L i p i ń s k a, Cechy definicyjne francuskich priameli..., op. cit.

19 Por. A. R e y, Le lexique: image el modèles, du dictionnaire à la lexicologie, Paris 1977, s. 198.

20 P. A r n a u d, op. cit., s. 198.

${ }^{21}$ G. S z p i 1 a, W poszukiwaniu prototypowych kontekstów paremicznych, [w:] Problemy frazeologii europejskiej, t. VII, Lublin 2005, s. 36. 
dla współczesnych użytkowników niezrozumiałe (np. W Gromnicę milszym w owczarni wilk jak słońce), ale również tych obecnie dosyć często używanych w żywym języku (np. Niedaleko pada jabłko od jabłoni). Ich interpretacja $\mathrm{w}$ powszechnym użyciu nierzadko bardzo różni się od prototypowej, rejestrowanej przez słowniki²2.

Ostatnią cechą dyferencjalną przysłowia, jaka pojawia się $\mathrm{w}$ pracach francuskich paremiologów, jest ich anonimowość, stawiana w opozycji do aforyzmów i sentencji ${ }^{23}$. Podstawowa trudność, z jaką w tym przypadku można się zetknąć, polega na nieuchwytności momentu, w którym dana paremia traci swój realny związek $\mathrm{z}$ autorem i staje się $\mathrm{w}$ odczuciu użytkowników anonimowa.

Nurt francuskich badań paremiologicznych podążał zdecydowanie szlakiem wytyczonym przez strukturalizm i semiologię. A.J. Greimas w podsumowaniu swoich rozważań stwierdził, że „Wyjaśnienia wstępne mają uzmysłowić konieczność stworzenia niezależnej dziedziny semantycznej: dowodzą one bowiem autonomicznego statusu formalnego elementów semiologicznych nazywanych tradycyjnie przysłowiami"24. Sądząc po obecnym dorobku badań paremiologicznych, ten naukowy postulat można uznać za w znacznym stopniu spełniony.

\section{Czeskie badania paremiologiczne}

Czeskie badania paremiologiczne mogą poszczycić się niezwykle cenną i bogatą tradycją, której rozwój wyznacza opublikowany w połowie XVII wieku zbiór przysłów czeskich autorstwa Jana Amosa Komenskiego 25 . Wydanie to przez współczesnych paremiologów nadal uważane jest za nowatorskie ze względu na tematyczny, a nie alfabetyczny układ jednostek paremicznych ${ }^{26}$, przez stulecia jedynie praktykowany.

W XX wieku za jedną z kluczowych prac w czeskiej paremiologii należy uznać obszerną rozprawę J. Mukařovskiego Przystowie jako część kontekstu ${ }^{27}$. Główna teza autora stoi w jawnej sprzeczności z poglądami francuskiej szkoły paremiologicznej. Zdaniem Mukařovskiego „przysłowie żyje

22 Fakt ten potwierdzają także badania T. Nikitiny: T. Н и к и т и н а, Современное состояние семантики паремий: пословица, [w:] Jezyk. Człowiek. Dyskurs, pod red. M. Hordy, W. Mokijenki, H. Waltera, Szczecin 2007, s. 133-146.

23 Por. D. B r a l e w s k i, Czy przysłowie jest jednostka języka?, [w:] Problemy frazeologii europejskiej, op. cit., s. 24.

24 A.J. Gr e i m a s, Przystowia i porzekadła, „Pamiętnik Literacki” 1978, z. 4, s. 314.

25 J.A. K o m e n s k ý, Moudrost starých Čechů, za zrcadlo vystavěna potomküm. Z rukopisu Lesenského, [w:] Spisy Jana Amosa Komenského. Vydal Jan Novák, číslo 2, Praha 1901.

26 В. М о к и е н к о, ор. cit., s. 89.

27 J. M u k a ř o v s k ý, Př́sloví jako součást kontextu, [w:] Cestami poetiky a estetiky, Praha 1971, s. 277-359; przedruk, [w:] „Literatura Ludowa” 1973, nr 4-5, s. 54-82. 
pełnym życiem tylko w kontekście” 28. Ponadto „Przysłowie jest nie tylko elementem kontekstu, ale jest również zdolne do wytwarzania kontekstu" 29. Zależność pomiędzy paremią a tekstowym otoczeniem jest zatem obustronna - przysłowie może determinować kontekst (np. niektóre opowiadania ludowe osnute na motywach przysłowiowych), częściej jednak to kontekst determinuje jeden i konkretny sens przysłowia, aktualizowany przez użytkowników języka w określonej sytuacji komunikacyjnej.

Analizując różne propozycje definicji przysłowia, J. Mukařovský wymienia zestaw najczęściej wymienianych cech dyferencjalnych: 1) obrazowość, 2) normatywność i zdolność do wartościowania, 3) ponadjednostkowy zakres obowiązywania, 4) uogólniający obraz i skrótowość, 5) możliwość użycia w wielu sytuacjach, 6) rytmiczność, 7) ludowość i tradycyjność30. Porządkując swoisty definicyjny chaos, autor rozpatruje cechy przysłowia w trzech najbardziej fundamentalnych - jego zdaniem - aspektach: 1) cechy związane ze stosunkiem przysłowia do podmiotu, 2) cechy charakteryzujące wewnętrzną budowę znaczeniową samego przysłowia, 3) cechy charakteryzujące przysłowie $\mathrm{w}$ stosunku do jego kontekstu ${ }^{31}$. W konsekwencji takiego podejścia teoretycznego J. Mukařovský dochodzi do interesujących wniosków, zgodnie z którymi jednostka paremiczna przez swoje "odsubiektywnienie" wykazuje swoją tradycyjność, kolektywność sankcji moralnej, o jakiej mowa w przysłowiach, oraz wskazuje na obecność "obcego“ podmiotu, a więć niejako wyższej instancji posiadającej społecznie akceptowalny etyczny "mandat" i autorytet. $Z$ drugim aspektem powiązane jest uogólniające znaczenie paremii, ich obrazowość i normatywność. Z trzecim - ich wieloznaczność, co w pełni pokrywa się z rezultatami badań G. Szpili czy T. Nikitiny, oraz funkcja swoistego eufemizmu komunikacyjnego: "Gdy w przysłowiu pojawi się obelga, nie dotyka ona wprost osoby, do której stosuje się przysłowie" 32 . W kontekście jednostka paremiczna doskonale sprawdza się w funkcji lakonicznego i trafnego podsumowania, sytuacyjnej rekapitulacji.

Tradycja J. Mukařovskiego jest widoczna nadal w czeskiej paremiologii i z powodzeniem kontynuowana nie tylko na terytorium Republiki Czeskiej. Warto zwrócić tutaj uwagę na prace F. Schindlera ${ }^{33}$, który na bazie szeroko zakrojonych badań ankietowych wykazał aktualność wielu przysłów i ich aktywne wykorzystywanie w szeroko rozumianym dyskursie publicznym.

28 Ibidem, s. 57.

29 Ibidem, s. 58.

30 Ibidem, s. 60.

31 Ibidem, s. 61.

32 Ibidem, s. 77.

${ }^{33}$ F. S c h i n d l e r, Sprichwort im heutigen Tschechischen: empirische Untersuchungen und semantische Beschreibung, München 1993. 
Drugim ważnym ośrodkiem badań czeskiej paremiologii jest Sankt Petersburg i prace L. Stiepanowej ${ }^{34}$.

W kontekście analizy współczesnych potencjalnych i realnych możliwości wykorzystywania przysłów w codziennej komunikacji mieszczą się badania korpusowe ${ }^{35}$ oraz próby ustalenia zakresu minimum paremiologicznego ${ }^{36}$.

Wspólnym mianownikiem czeskich badań paremiologicznych jest kontekst $\mathrm{i}$ jego rola $\mathrm{w}$ aspekcie funkcjonalnym jednostek paremicznych. Wnioskiem zaś wynikającym z przeprowadzonych analiz zarówno natury teoretycznej, jak i praktycznej jest niesłabnąca aktualność przysłów we współczesnym dyskursie. Są one nadal chętnie i skutecznie wykorzystywane przez użytkowników, a ich potencjał jako jednostek systemu językowego nie tylko nie wyczerpał się, ale wciaż zyskuje nowe oblicze w postaci różnorodnych transformacji paremiologicznych ${ }^{37}$.

\section{Fińskie i estońskie badania paremiologiczne}

Badania paremiologiczne fińskich oraz estońskich językoznawców i etnografów zaistniały na szerszą skalę we wschodnioeuropejskim obiegu naukowym dzięki wydawanemu w Helsinkach przez Fińskie Towarzystwo Literatury rocznikowi „Proverbium”38. Największe znaczenie miały dla rozwoju współczesnej paremiologii przede wszystkim prace Matti Kuusiego i Arvo Krikmanna.

W 1978 r. w tomie Паремиологический сборник został przedrukowany artykuł Arvo Krikmanna Niektóre aspekty semantycznej nieokreśloności przysto-

34 Л.И. С т е п а н о в а, Фразеологические единицы с именами собственными (на маmериале чешского языка). Автореф. дисс. ...канд. филол. наук, Ленинград 1985; tejże, Очерки по истории чешской фразеологии, Санкт-Петербург 2003.

35 Por. R. B 1 a t n á, Czech proverbs vanishing in the black hole. Elaborated on the material of the Czech National Corpus, [w:] Europhras' 97. Phraseology and Paremiology, Bratislava 1998, s. 24-29; F. Č e r m á k, Usage of proverbs. What the Czech National Corpus Shows, [w:] Europhras' 97..., op. cit., s. 37-49; M. N o v á k o v á, All that glitters in the newspapers is not proverb. Worked on the basis of the material from the Czech National Corpus, [w:] Europhras' 97..., op. cit., s. 250-256.

${ }^{36}$ F. Č e r m á k, Paremiological Minimum of Czech: The Corpus Evidence, [w:] Flut von Texten - Vielvalt der Kulturen. Ascona 2001 zur Methodologie und Kulturspezifik der Phraseologie, Hrsgb. H. Burger, A. Häcki Buhofer, G. Greciano, Hohengehren 2003, s. 15-31.

37 Por. F. S c h i n d l e r, D. B i t t n e r o v á, Česká př́sloví. Soudobý stav konce 20. století, Praha 1997.

38 Rocznik „Proverbium. Bulletin d'information sur les recherches parémiologiques” ukazywał się w Helsinkach w latach 1965-1975. Od 1985 pod nazwą „Proverbium: Yearbook of International Proverb Scholarship" wydawany jest przez University of Vermont w USA pod red. W. Miedera. 
wia ${ }^{39}$. Tytułową nieokreśloność jednostek paremicznych estoński badacz rozpatruje w kilku aspektach. Po pierwsze, przysłowie jest nieokreślone denotacyjnie - konkretyzacja dokonuje się zawsze w ściśle określonej sytuacji komunikacyjnej. W izolacji pozostaje ono tylko potencjalnym znakiem językowym. Po drugie, nieokreśloność dotyczy także aspektu funkcjonalno-pragmatycznego. To od intencji mówiącego zależy, czy dana paremia zostanie użyta jako stwierdzenie, ocena (pozytywna albo negatywna) lub nakaz. Po trzecie, niejednoznaczna pozostaje również wartość aksjologiczna przysłowia ${ }^{40}$. Informacyjna nieokreśloność jednostek paremicznych - zdaniem A. Krikmanna - polega na jej retrospektywnym lub prognostycznym użyciu (nadawca komunikatu za pomocą przysłowia stwierdza zaistniały w przeszłości fakt lub zjawisko, albo wyraża swoją prognozę).

Badania M. Kuusiego wpisują się $\mathrm{w}$ problematykę podjętą przez A. Krikmanna. Jednym z głównych zagadnień rozpatrywanych przez fińskiego paremiologa jest zależność pomiędzy potencjalnym znaczeniem przysłowia a konkretną sytuacją jego użycia ${ }^{41}$. Drugim obszarem są problemy teoretyczne, w szczególności klasyfikacja jednostek paremicznych. Za szczególnie wartościową i interesującą należy uznać analizę tzw. paremii ilościowych ${ }^{42}$, które - w opinii M. Kuusiego - z uwagi na swoją semantyczną wyrazistość łatwo poddają się obiektywnej typologizacji. Autor wyróżnia kilkanaście grup i kilkadziesiąt podgrup semantyczno-strukturalnych, ilustrując je przykładami przysłów z różnych języków świata ${ }^{43}$,

39 А.А. К р и к м а н н, Некоторые аспекты семантической неопределенности пословицы, [w:] Паремиологический сборник. Пословица. Загадка (структура, смысл, текст), под ред. Г.Л. Пермякова, Москва 1978, с. 82-104; oryginalny tekst artykułu w języku angielskim (A. Krikmann, Some Additional Aspects of Semantic Indefiniteness of Proverbs) został opublikowany w elektronicznym roczniku „De Proverbio” 1999, vol. 5, nr 2, [w:] źródło elektroniczne: http://www.deproverbio.com/display.php?a=4\&f=DPjournal\&r=DP,5,2,99 /index.html (30.08.2012).

40 A. Krikmann przywołuje przykład szkockiego przysłowia Rolling stones gather no moss (Toczący się kamień mchem nie obrasta), które w zależności od interpretacji nabiera pozytywnego bądź negatywnego znaczenia: w wersji angielskiej - 'tułacz, człowiek, który nie może znaleźć swojego miejsca na świecie'; w wersji szkockiej - 'człowiek stale aktywny i stale podejmujący nowe wyzwania'. A.A. K r i k m a n n, op. cit., s. 96.

${ }^{41}$ M. K u u s i, On the Aptness of Proverbs, „De Proverbio” 1998, vol. 4, nr 1, [w:] źródło elektroniczne: http://www.deproverbio.com/display.php?a=4\&f=DPjournal\&r=DP,4,1,98 /index.html (30.08.2012).

${ }^{42} \mathrm{M.} \mathrm{К} \mathrm{у} \mathrm{у} \mathrm{с} \mathrm{и,} \mathrm{К} \mathrm{вопросу} \mathrm{о} \mathrm{международной} \mathrm{системе} \mathrm{пословичных} \mathrm{типов} \mathrm{(Опыт} \mathrm{клас-}$ сификации количественных послович), [w:] Паремиологический сборник. Пословица. Загадка (структура, смысл, текст), под ред. Г.Л. Пермякова, Москва 1978, с. 53-81; Oryginalny tekst artykułu w języku angielskim (M. K u u s i, Towards an International Tipesystem of Proverbs) został opublikowany w roczniku „Proverbium” 1972, vol. 19.

43 Np.: podgrupa semantyczno-strukturalna 'Одна составная часть Х-а - это не весь $X^{\prime}$ reprezentowana jest następującymi jednostkami paremicznymi: Один чудесный 
co niewątpliwie czyni jego spostrzeżenia obiektywnymi w skali globalnej. Wniosek z badań M. Kuusiego wskazuje na jednolitość i uniwersalizm procesu odzwierciedlenia faktów $\mathrm{z}$ rzeczywistości pozajęzykowej w jednostkach paremicznych różnych języków i kultur, jak wskazuje zebrany przez badacz materiał faktograficzny - niekiedy nawet bardzo od siebie odległych (przysłowia europejskie w porównaniu do japońskich, chińskich, hindi, malajskich, mongolskich, samoa, maori i in.).

M. Kuusi w typologii paremiologicznej wyróżnia także przysłowia synonimiczne (realizujące tę samą ideę lub - inaczej - pole semantyczne), przysłowia zbudowane na identycznym modelu strukturalnym oraz przysłowia oparte na wspólnym obrazie metaforycznym ${ }^{44}$. Klasyfikacja ta wykazała istnienie wewnętrznych zależności w systemie paremiologicznym, opartym na strukturalno-semantyczno-metaforycznych determinantach ${ }^{45}$, oraz zobrazowała jego wewnętrzne uporządkowanie.

Dorobek fińskich i estońskich paremiologów skupionych wokół rocznika naukowego „Proverbium” jest doniosły przede wszystkim w dwóch obszarach - typologii jednostek paremicznych oraz frazeologii konfrontatywnej na bardzo szerokim i językowo zróżnicowanym materiale faktograficznych. Szczególnie analizy A. Krikmanna są istotnym wkładem w rozwój badań nad tzw. uniwersaliami językowymi.

\section{Amerykańskie badania paremiologiczne}

Mówiąc o rozwoju współczesnej paremiologii, nie sposób pominąć bardzo ważnego i wpływowego ośrodka naukowego, jakim są Stany Zjednoczone, szczególnie zaś University of Vermont ${ }^{46}$, gdzie już od wielu lat badaniami paremiologicznymi kieruje Wolfgang Mieder, redaktor naczelny wspomnianego wcześniej rocznika „Proverbium”.

W latach 70. analizy struktury jednostek paremicznych przeprowadził Alan Dundes z University of California w Berkeley. Jednym z głównych celów amerykańskiego badacza było opisanie struktury szeroko rozumia-

день лета не делает; Одно дерево не образует леса; Из одного кирпича стену не воздвигнешь; Из одного колоса снопа не получится; Одна пчела - это еще не рой; Один еврей - не ярмарка; Одна речь - не пословица itd.; М. К у у с и, К вопросу о международной системе..., op. cit., s. 68-69.

${ }_{44}$ M. K u u s i, Ein Vorschlag für die Terminologie der parömiologischen Strukturanalyse, „De Proverbio" 1998, vol. 4, nr 1, [w:] źródło elektroniczne: http://www.deproverbio. com/display.php?a=4\&f=DPjournal\&r=DP,4,2,98/index.html (30.08.2012).

45 Por. W. Z m a r z e r, O pojęciu systemu paremiologicznego, „Przegląd Rusycystyczny" 1998, z. 3-4, s. 71-79.

${ }^{46}$ Department of German and Russian University of Vermont, Burlington, Vermont USA. 
nego folkloru, którego nieodłącznym elementem są przysłowia ${ }^{47}$. Ich eksploracje można prowadzić przynajmniej $\mathrm{w}$ trzech podstawowych aspektach: 1) pod względem obrazu metaforycznego, 2) pod względem treści, 3) pod względem formy, z których ostatni wykazuje najwyższy stopień unifikacji pomiędzy odmiennymi kulturami i językami. Obraz metaforyczny natomiast najbardziej determinowany jest specyfiką kulturową i realiami pozajęzykowymi, jakie wpłynęły na kształtowanie się konkretnych jednostek paremicznych. Alan Dundes zauważa formalne analogie pomiędzy zagadką a przysłowiem, których struktura oparta jest na konstrukcji „temat - remat" 48 , przy czym zasadnicza różnica polega na tym, że w przysłowiu remat jest powszechnie znany, a w zagadce - ukryty. Przytłaczająca większość przysłów realizuje się $\mathrm{w}$ kilku zaledwie podstawowych modelach strukturalnych, np. A=B (Хорошо смеется тот, кто смеется последним), $\mathrm{A} \neq \mathrm{B}$ (Одна ласточка не делает весны), $\mathrm{A}<\mathrm{B}$ lub A>B (Судить после легче, чем судить до события), со świadczy o stosunkowo prostej i uporządkowanej architekturze paremiologicznego podsystemu języka.

Fundamentalną dla amerykańskiej paremiologii była monografia Archera Taylora, folklorysty i językoznawcy z Uniwersytetu Waszyngtona w St. Louis ${ }^{49}$, w której autor podważa słuszność definicyjnych dociekań dotyczących przysłowia i jego natury. Cechy jednostki paremicznej są zbyt nieuchwytne, aby móc pokusić się o stworzenie optymalnej i zarazem uniwersalnej definicji. A. Taylor za zdecydowanie bardziej zasadne uważa badania dotyczące treści i stylu przysłów ${ }^{50}$. Szczególnie pozytywnie odnosi się do klasyfikacji ideograficznych, które najlepiej - w ocenie badacza - ukazują specyfikę etnograficzną danego obszaru językowego. Ze względu na kryterium tematyczno-funkcjonalne A. Taylor wyróżnił i szczegółowo opisał przysłowia historyczne (np. Unter dem Krummstab ist gut wohnen), przysłowia obyczajowe (np. Ein Engel flog durchs Zimmer), przysłowia-proroctwa (np. Austria erit ultima in orbe) ${ }^{51}$.

A. Taylor w swoich pracach wielokrotnie zwracał uwage na fundamentalne znaczenie we współczesnych badaniach paremiologicznych bibliografii i zbiorów przysłów o zasięgu zarówno krajowym, jak i międzynarodo-

47 А. Д а н д и с, О структуре пословицы, [w:] Паремиологический сборник. Пословица. Загадка (структура, смысл, текст), под ред. Г.Л. Пермякова, Москва 1978, s. 13-34.

48 Ibidem, s. 21.

49 A. T a y 1 o r, The Proverb, Hatboro 1962.

50 A. T a y 1 o r, The content of proverbs, „De Proverbio” 1996, vol. 2, nr 2, [w:] źródło elektroniczne: http://www.deproverbio.com/display.php?a=4\&f=DPjournal\&r=DP,2,2,96 /index.html (01.09.2012).

51 Ibidem. 
wym $^{52}$. Za ważne uznał także analizy konfrontatywne i translatoryczne, szczególnie w kontekście poszukiwań międzyjęzykowych paralel premiologicznych ${ }^{53}$.

W problematykę podjętą przez A. Taylora w pełni wpisują się badania W. Miedera, który cyklicznie od 1977 roku wydaje obszerne międzynarodowe bibliografie paremiologiczne ${ }^{54} \mathrm{~W}$ formie zestawień opracowań i szkiców dotyczących zarówno kwestii teoretycznych, jak i analizy konkretnych jednostek paremicznych ${ }^{55}$. Bibliografie te stanowią nieocenioną pomoc przede wszystkim dla paremiologów, ale także dla kulturologów i etnografów.

Równie istotne są prace teoretyczne, w których W. Mieder podkreśla rolę centralnego składnika definicji przysłowia, jakim jest tradycyjność. Termin ten „obejmuje zarówno aspekt wieku, jak i rozpowszechnienia, które muszą być zawarte $\mathrm{w}$ wypowiedzeniu, jeśli ma ono być uważane za przysłowie" 56 . To, czy dane zdanie spełnia warunki definicyjne, można sprawdzić jedynie w drodze badań „zewnętrznych”, jak je określa W. Mieder, a więc przez analizę źródeł leksykograficznych, tekstów literackich, żywego języka. Maksymalny zakres rozpowszechnienia przysłowie zyskuje dzięki swojej względnie stałej i niepodatnej na modyfikacje formie. Fakt ten jednak nie wyklucza transformacji, o czym W. Mieder sygnalizował już kilkadziesiąt lat wcześniej przed współcześnie obserwowaną swoistą eksplozją tzw. antyprzysłów. Pod jego kierunkiem w ostatnim czasie ukazały się liczne publikacje traktujące o transformacjach paremicznych ${ }^{57}$. Anali-

52 A. T a y 1 o r, Problems in the study of proverbs, „De Proverbio” 1996, vol. 2, nr 2, [w:] źródło elektroniczne: http://www.deproverbio.com/display.php?a=4\&f=DPjournal\&r $=\mathrm{DP}, 2,2,96 /$ index. html (01.09.2012).

53 Ibidem.

${ }^{54}$ W. M i e d e r, International Bibliography of Explanatory Essays on Individual Proverbs and Proverbial Expressions, Bern-Frankfurt am Mein-Las Vegas 1977; tegoż, Proverbs in Literature: An International Bibliography, Bern-Frankfurt am Mein-Las Vegas 1978; tegoż, International Proverb Scholarship: An Annotated Bibliography, New York 1982; tegoż, International Proverb Scholarship: An Annotated Bibliography. Supplement I (1800-1981), New-York 1990; tegoż, International Proverb Scholarship: An Annotated Bibliography. Supplement II (1982-1991), New-York-London 1993; tegoż, International Proverb Scholarship: An Annotated Bibliography. Supplement III (1990-2000), New-York-Bern-Berlin-Bruxelles-Frankfurt am Mein-Oxford-Wien 2001.

55 Por. S. P r ę d o t a, O bibliografiach paremiologicznych Wolfganga Miedera, "Literatura Ludowa" 1993, z. 3, s. 65-70.

56 W. M i e d e r, Ogólne uwagi o naturze przystów, „Literatura Ludowa” 1993, z. 3, s. 52 .

57 Por. W. Mi e d e r, A. Tó th e - Li t o v ki n a, Twisted Wisdom. Modern Anti-proverbs, "Proverbium” 1999; W. M i e d e r, Antisprichwörter. 1. Volume, Wiesbaden 1982; tegoż, Antisprichwörter. 2. Volume, Wiesbaden 1985; tegoż, Antisprichwörter. 3. Volume, Wiesbaden 1989; A. L i t o v k i n a, W. M i e d e r, Old Proverbs Cannot Die. They Just Diversify: A Collection of Anti-Proverbs, Burlington 2005. 
zując krąg zainteresowań badawczych W. Miedera, należy wspomnieć także o zagadnieniu minimum paremiologicznego ${ }^{58}$, które $\mathrm{z}$ kolei mieści się w kręgu problematyki aktualności przysłów we współczesnych językach europejskich.

Amerykańskie badania paremiologiczne - obok słowiańskich w Europie - można z powodzeniem uznać za najbardziej dynamicznie rozwijające się 59 . W ostatnim czasie widać stopniowy odwrót od czysto strukturalistycznych analiz w kierunku problematyki funkcjonalnej, komunikacyjnej, kulturologicznej oraz - nie mniej istotnej - dokumentacyjnej.

Z przyczyn obiektywnych nie sposób w tak krótkim opracowaniu omówić wszystkich zagadnień, ograniczając się nawet tylko do wybranych czterech nurtów współczesnej paremiologii. Cel artykułu był jednak o wiele skromniejszy - dokonanie syntezy i przeglądu problematyki badań paremiologicznych oraz zwięzłe przedstawienie najważniejszych publikacji z literatury przedmiotu. Pozostaje wyrazić nadzieję, że oczekiwania czytelników co do niniejszego tekstu zostaną spełnione, a paremiologia zyska dzięki temu nieco szerszy badawczy kontekst.

58 W. M i e d e r, Paremiological minimum and cultural literacy, "De Proverbio" 1995, vol. 1, nr 1, [w:] źródło elektroniczne: http://www.deproverbio.com/display.php?a=4\&f =DPjournal\&r=DP,1,1,95/MINIMUM.html (01.09.2012).

59 Por. prace m.in. R.D. Abrahama, S. Arrory, N. Barleya, D. Crama, B. Kirshenblatt-Gimblett, G. Milnera, P. Grzybka, N.R. Norricka, P. Seitela, B.J. Whitinga, H.A. Hassa, G. Paczolay, A. Reznikova. 